Dept. of Bacteriology,

Animal Health Research Institute, Shebin El-Koom.

\title{
APPLICATION OF ELECTEROPHORESIS AND IMMUNOBLOT IN DIAGNOSIS OF PSEUDOMONAS AERUGINOSA ISOLATED FROM RESPIRATORY SYSTEM OF CAMELS
}

(With 4 Tables and 2 Figures)

By

\section{EMAN M. SHARAF and HODA M. ABD EL-MONEM*}

* Dept. of Biotechnology, Animal Health Research Institute, Dokki, Giza

(Received at 12/6/2011)

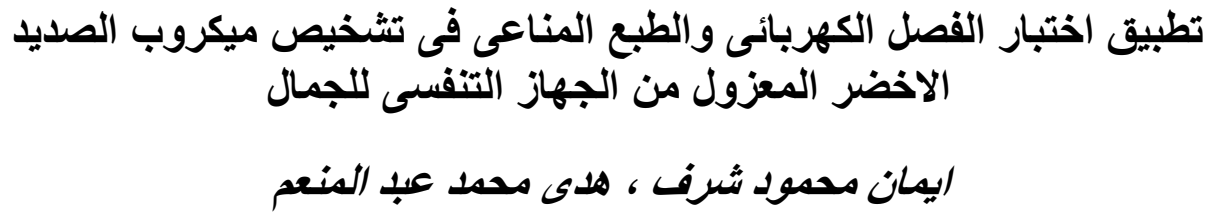

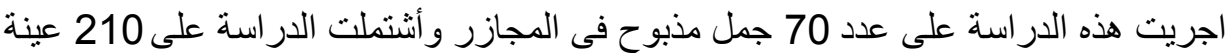

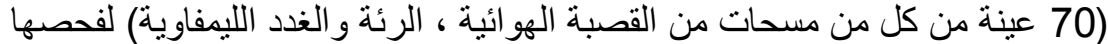

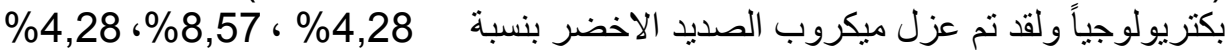

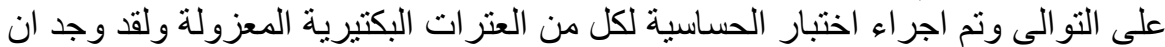

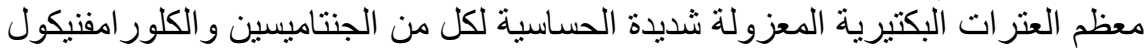

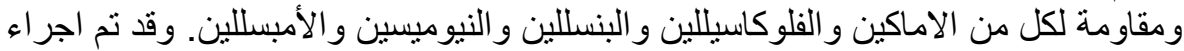

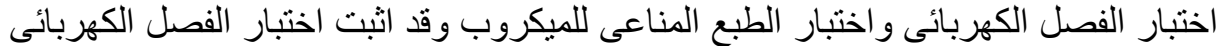

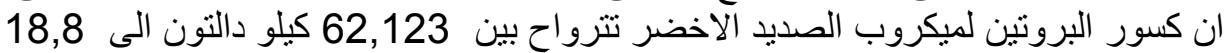

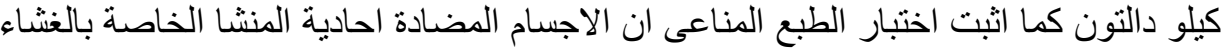

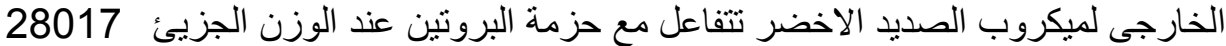

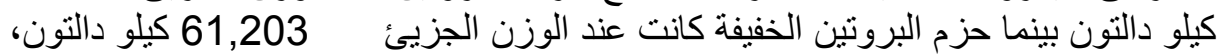
46,148 كيلو دالتون، 35,024 كيلو دالتون، 8,1954 كيلو دالتون التئن

\section{SUMMARY}

This Study was carried out on 70 slaughtered camels. 210 samples (70 each of tracheal swabs, lungs and lymph nodes) for isolation of Pseudomonas aeruginosa. Obtained results declared that Pseudomonas aeruginosa could be detected in $3(4.28 \%), 6(4.28 \%)$ and $3(4.28 \%)$ of the examined samples of tracheal swabs, lungs and lymph nodes respectively. The in vitro antibiotic sensitivity tests for the isolated 
bacteria were discussed. The results showed that Pseudomonas aeruginosa was sensitive to Gentamycin and Chloramephenicol, while this organism was resistant to Amikacin, Flucloxacillin, Penicillin, Neomycin and Ampicillin. SDS- PAGE demonstrated that the protein fractions of Pseudomonas aeruginosa ranged between $62.123 \mathrm{KDa}$ and 18.8 KDa. Immunoblotting analysis of the OMPs of Pseudomonas aeruginosa demonstrated that the monoclonal antibody specific to Pseudomonas aeruginosa OMPs reacted with protein band at molecular weight of $28.017 \mathrm{KDa}$ (more immunogenic band) while faint bands were revealed at $61.203 \mathrm{KDa}, 46.148 \mathrm{KDa}$ and $8.1954 \mathrm{KDa}$.

Key words: Camels, respiratory system, Pseudomonas aeruginosa.

\section{INTRODUCTION}

Camel is an animal of considerable importance in Egypt since it is one of the major sources of meat production where its meat represents $66.46 \%$ of total meat obtained from the imported animals for slaughter purposes (Anon, 1986). Also the camel plays vital socioeconomic roles and supports the survival of millions of people in Asia and Africa. It is being used as a source of protein, milk, hide as well as quite and effective mean of transport (Chowdhary, 1986).

Respiratory diseases of camels continue to be a major cause of economic loss and adverse on animal. Stress of cold weather, rain, bad hygiene and high humidity rate were incriminated to increase the respiratory infection. Respiratory affection is the main cause of death among camel calves allover the world (Chowdhary, 1986; Khanna et al., 1992).

Several species of organisms could be isolated from both apparently healthy and affected respiratory tract of camel, Pseudomonas aeruginosa is one of them (Amany, 2000; Fatma et al., 2001; Seddak, 2002).

Electrophoretic analysis and immunoblotting are considered one of the most advanced techniques used for characterization of antigens (Laemmli, 1970; Towbin et al., 1979).

Hence, the present work aimed to isolate Pseudomonas aeruginosa from respiratory system of camels, in-vitro antibiotic sensitivity against the isolated strains and identification of Pseudomonas aeruginosa by Sodium dodecyl sulfate / polyacrylamid gel electrophoresis (SDS-PAGE) and Immunoblotting 


\section{MATERIALS and METHODS}

\section{1- Sampling:}

A total of 210 samples including 70 each of tracheal swabs, lungs and thoracic lymph nodes tissues were collected under aseptic condition from 70 slaughtered camels in different abattoirs. All samples were transported as quickly as possible to the laboratory in an ice box for bacteriological examination.

\section{2- Bacteriological Examination:}

Each sample was cultured into cetrimide broth and incubated at $42^{\circ} \mathrm{C}$ for 48 hours. A loopful was taken from the enrichment broth and cultured onto cetrimide agar (Oxoid. M3) and Pseudomonas Agar f base (King et al., 1954). After incubation the presence of Pseudomonas aeruginosa was detected by blue green pigment production (soluble in both water and chloroform) and the cultures have a distinctive smell (fruity smell) on the media used due to 2 amino acetophenone production. From the suspected colonies, agar slants were made and incubated for further identification according to king et al. (1954) and incubated at $42^{\circ} \mathrm{C}$ for 48 hours.

\section{3- In-vitro antibiotic sensitivity test:}

The disc diffusion technique was performed on the isolated bacteria from infected cases according to Finegold and Martin (1982) using Norfloxacin, Cefoperazone, Amikacin, Flucloxacillin, Penicillin, Neomycin, Ampicillin, Gentamycin and Chloramephenicol. The degree of sensitivity was determined and interpreted according to Oxoid (1998).

\section{4- Preparation of outer membrane protein antigen (OMPs)}

Each of the strains was cultivated in $500 \mathrm{ml}$ of broth medium for 2 days at $37^{\circ} \mathrm{C}$, the cells were sedminted by centrifugation at $13,000 \mathrm{XG}$ for 20 minutes, washed twice in $0.25 \mathrm{M} \mathrm{NaCl}$ and resuspended in $1.5 \mathrm{ml}$ of $\mathrm{M} \mathrm{NaCl}$. One $\mathrm{ml}$ of cell suspension was combined with $2 \mathrm{ml}$ of phenol- acetic acid- water $(2: 1: 0.5 \mathrm{w} / \mathrm{v} / \mathrm{v})$ then after 3 to 4 hours at $25^{\circ} \mathrm{C}$, the insoluble material was sedimented by centrifugation at $30,000 \mathrm{XG}$ for 15 minutes and the supernatant fluid was decanted and maintained at $5{ }^{\circ} \mathrm{C}$ until used (Dubreuil et al., 1988).

\section{5- Electrophoresis for OMPs}

Sodium dodecyl sulphate polyacrylamide gel electrophoresis (SDS- PAGE) of the OMPs samples of Pseudomonas aeruginosa isolates were carried out as described by Laemmli (1970) using prestained high molecular weight standard marker (Sigma Chemical 
company St. Louis Mo 63178 USA. The bands of mol.w. protein marker from top to bottom are: 66. KDa, $45 \mathrm{KDa}, 34.7 \mathrm{KDa}, 24 \mathrm{KDa}, 18.4 \mathrm{KDa}$ and 14.3 KDa.

After electrophoresis, the gel was stained by coomassi blue stain and distained according to Hitchock and Brown (1983). Dendogram was constructed for similarity with each isolates (Advanced American Biotechnology, UPGMA, USA).

6- Imunblotting (Western blot) according to Towbin et al. (1979):

After electrophoresis the gels were transferred onto nitrocellulose membrane. The membrane were incubated with rabbit anti-bovine Ig G conjugated with HRP (Horse raddish peroidase), using Biolab - broad rang pre- stained Molecular weight marker.

The color was developed by adding the substrate (30mg 4-chloro - 1-naphthol dissolved, $10 \mathrm{ml}$ cold methanol, $30 \mu$ hydrogen peroxide in $50 \mathrm{ml}$ PBS $\mathrm{pH}$ 7.4). At the end of transfer process, protein bands were checked on nitrocellulose membrane by staining with $1 \%$ amido black stain.

\section{RESULTS}

Table 1: Incidence of Pseudomonas aeruginosa isolated from the respiratory tract of camels samples.

\begin{tabular}{|c|c|c|c|}
\hline \multirow{2}{*}{ Types of samples } & \multirow{2}{*}{$\begin{array}{c}\text { No. } \\
\text { examined }\end{array}$} & \multicolumn{2}{|c|}{ Positive samples } \\
\cline { 3 - 4 } & & No. & $\%$ \\
\hline Tracheal Swabs & 70 & 3 & $4.3 \%$ \\
\hline Lungs & 70 & 6 & $8.6 \%$ \\
\hline Lymph nodes & 70 & 3 & $4.3 \%$ \\
\hline Total & 210 & 12 & $5.7 \%$ \\
\hline
\end{tabular}


Table 2: Antibiotic sensitivity of the isolated Pseudomonas aeruginosa from the respiratory tract of camels.

\begin{tabular}{|l|c|c|c|}
\hline \multicolumn{1}{|c|}{$\begin{array}{c}\text { Antibiotic and } \\
\text { chemotherapeutic agents }\end{array}$} & Conc. & Symbol & Reaction \\
\hline Norfloxacin & $10 \mathrm{ug}$ & NOR & $\mathrm{M}$ \\
\hline Cefoperazone & $75 \mathrm{ug}$ & CFP & $\mathrm{M}$ \\
\hline Amikacin & $30 \mathrm{ug}$ & AK & $\mathrm{R}$ \\
\hline Flucloxacillin & $5 \mathrm{ug}$ & FL & $\mathrm{R}$ \\
\hline Penicillin & $10 \mathrm{ug}$ & $\mathrm{P}$ & $\mathrm{R}$ \\
\hline Neomycin & $30 \mathrm{ug}$ & $\mathrm{N}$ & $\mathrm{R}$ \\
\hline Ampicillin & $30 \mathrm{ug}$ & AM & $\mathrm{R}$ \\
\hline Gentamycin & $10 \mathrm{ug}$ & $\mathrm{GM}$ & $\mathrm{S}$ \\
\hline Chloramephenicol & $30 \mathrm{ug}$ & $\mathrm{C}$ & $\mathrm{S}$ \\
\hline
\end{tabular}

$\mathrm{S}=$ sensitive

$\mathrm{M}=$ Moderate sensitivity

$\mathrm{R}=$ Resistant

Table 3: The molecular weight (mol. w.) of electrophoresis of Pseudomonas aeruginosa compared with the mol.w. of the marker.

\begin{tabular}{|c|c|c|}
\hline Lanes Rows & $\begin{array}{c}\text { Marker } \\
(\text { mol. W. })\end{array}$ & $\begin{array}{c}\text { Lane 1 } \\
\text { (mol. W. })\end{array}$ \\
\hline R1 & 66 & 62.123 \\
\hline R2 & 45 & 41.158 \\
\hline R3 & 34.7 & 39.158 \\
\hline R4 & 24 & 13.631 \\
\hline R5 & 18.4 & 18.8 \\
\hline R6 & 14.3 & \\
\hline
\end{tabular}


Photo 1: Electrophoretic profile of Pseudomonas aeruginosa isolate detected by SDS-PAGE with coomassie stained

\section{Lane 1}

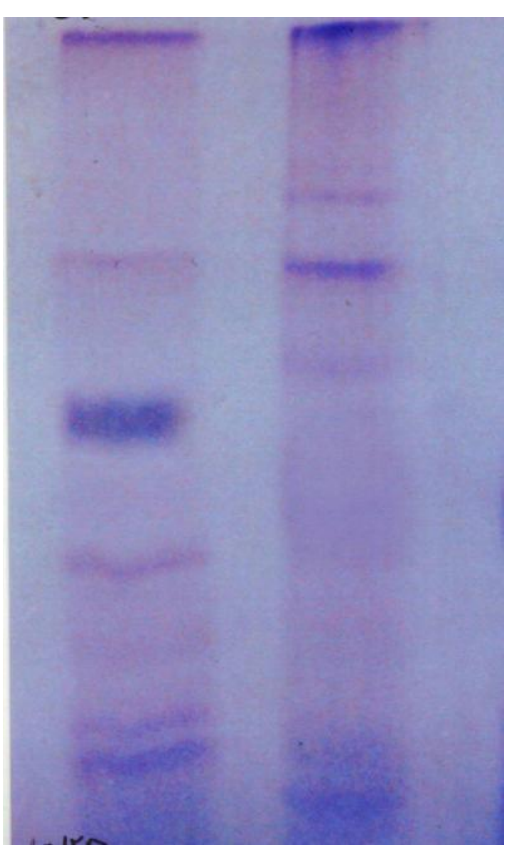

M: Molecular weight marker (Sigma chemical company st. Louis Mo 63178 USA. the bands of mol.w. protein marker from top to bottom are: 66. KDa, $45 \mathrm{KDa}, 34.7 \mathrm{KDa}, 24 \mathrm{KDa}, 18.4 \mathrm{KDa}$ and 14.3 KDa)

$\mathrm{M}=$ Marker

Lane 1= Pseudomonas aeruginosa

$\mathrm{KDa}=$ Kilodalton .

Table 4: The molecular weight (mol. w.) of western blot of Pseudomonas aeruginosa compared with the mol.w. of marker.

\begin{tabular}{|c|c|c|}
\hline Lanes Rows & $\begin{array}{c}\text { Marker } \\
\text { (mol. W. })\end{array}$ & $\begin{array}{c}\text { Lane 1 } \\
\text { (mol. W. })\end{array}$ \\
\hline R1 & 175 & 61.203 \\
\hline R2 & 83 & 46.148 \\
\hline R3 & 62 & 35.024 \\
\hline R4 & 47.5 & 28.017 \\
\hline R5 & 32.5 & 8.195 \\
\hline R6 & 25 & \\
\hline R7 & 16.5 & \\
\hline
\end{tabular}


Photo 2: Immunoblot of SDS-PAGE of outer membrane protein extracted from and transferred onto nitrocellulose paper recognized by rabbit antiserum, detected with HRP (Horse raddish peroidase) and visualized with color substrate.

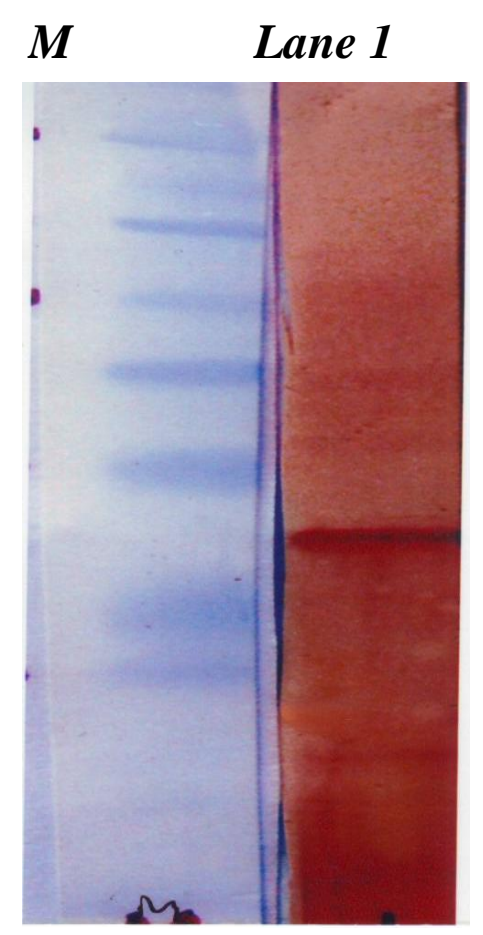

M: Molecular weight marker (Biolab - broad rang pre- stained Molecular weight marker)

$\mathrm{M}=$ Marker.

Lane 1= Pseudomonas aeruginosa.

$\mathrm{KDa}=$ Kilodalton .

\section{DISCUSSION}

Bacterial infection of the respiratory tract of camels represents important problems confronting animal production. The present study deals with the pathogenic bacteria in the respiratory tract of slaughtered camels (Amany, 2000).

The results recorded in Table 1 showed that bacteriological examination of 70 tracheal swab samples, 70 lung samples and 70 lymph node samples collected from 70 slaughtered camels revealed that $3(4.28 \%), 6(8.57 \%)$ and $3(4.28 \%)$ respectively were positive for 
Pseudomonas aeruginosa (Buxton and Fraser, 1977), also these results nearly agree with those of Fatma et al. (2001).

In vitro, the susceptibility of the isolated Pseudomonas aeruginosa to different antibiotics is represented in Table 2; the isolated bacteria was highly sensitive to Gentamycin and Chloramephenicol while was resistant to Amikacin, Flucloxacillin, Penicillin, Neomycin and Ampicillin. These findings are partially in agreement with those mentioned with Riad (1989); Abd El-kader (1992); Thabet (1993); Ahmed (1994); Seddak (2002).

The resistance of bacterial isolates to some antibiotics may be attributed to wrong dosage, duration of treatment and route of administration (Amstutz and Armostrong, 1982).

SDS- PAGE is considered as a powerful tool to differentiate genetically related microorganisms (Wassenaar and Newell, 2000)

Electrophoresis of protein was carried out in polyacrylamide gel $(10 \%)$ where protein was dissociated into their individual polypeptide subunits. This method was discussed by (Laemmli, 1970; Gardon, 1980; Smith, 1984).

In order to identify the electrophoretic profile of the isolated Pseudomonas aeruginosa, the protein components were separated by SDS- PAGE and resolved into protein bands as shown in Photo (1) and Table 3. The protein fractions of Pseudomonas aeruginosa ranged between $62.123 \mathrm{KDa}$ and $18.8 \mathrm{KDa}$. The result is nearly similar to that obtained by Doring et al. (1987); Pablo et al. (1989); Jyotsna et al. (2005); Jennifer et al. (2009).

Immunoblotting analysis of the OMPs of Pseudomonas aeruginosa demonstrated that the monoclonal antibody specific to Pseudomonas aeruginosa OMPs reacted with protein band at molecular weight of $28.017 \mathrm{KDa}$ (more immunogenic band) while faint bands were revealed at $61.203 \mathrm{KDa}, 46.148 \mathrm{KDa}$ and $8.1954 \mathrm{KDa}$ as shown in photo (2) and Table (4). This result was nearly similar to that obtained by (Pablo et al., 1989; Molakala et al., 1992; Jennifer et al., 2009).

Finally, more efforts must be done to overcome respiratory disorders problem. Periodical clinical and bacteriological examination of apparently healthy animals should be done to avoid misuse of antibiotics. Adequate hygienic measures and proper management of animals would reduce the degree of exposure of animals to disease producing agents. SDS- PAGE and Immunoblotting analysis may be considered as a rapid, reliable, sensitive and diagnostic method to characterize Pseudomonas aeruginosa. 


\section{REFERENCES}

Abd El-Kader, H.A. (1992): Studies on bacterial and parasitic causes of respiratory infection among dairy animals. Ph. D. Thesis (Microbiology Department), Fac. Vet. Med., Assiut University.

Ahmed, F.A. (1994): Studies on some types of bacteria causing respiratory infection among new born calves. M.V. Sc, Thesis (Microbiology Department), Fac. Vet. Med., Zagazig University. Amany, N.D.A. (2000): A contribution words the bacterial harboring and affecting the respiratory tract of camel. M.V.Sc. Thesis (Microbiology Department), Fac. Vet. Med. Cairo. Univ.

Amstutz, H.; Mote, R. and Armostrong, C. (1982): Antimicrobial resistance of strains of Pasteurella species isolated from feedlot cattle. Bovine Practice, 16: 52-55.

Anon (1986): Vet Service Organization publication, Mist Agri. A.R.E.

Buxton, A. and Fraser, G. (1977): Animal Microbiology. Black well Scientific Publication, Oxford, London.

Chowdhary, B. (1986): Some important biological and production characters of the Bikaner: camels. Ind. J. Anim. Prod. Manag., 2 (3): $145-151$.

Doring, G.; Maier, M.; Muller, E.; Bibi, Z.; Tummler, B. and Kharazmi, A. (1987): Virulence of Pseudomonas aeruginosa. Antibiot. Chemother (Base) 39: 136- 148.

Dubreuil, J.D.; Longan, S.M.; Cubbage, T.J.; Ferris, F.G. and Trust, T.J. (1988): Structural and biochemical analysis of a surface protein of C. fetus. J. Bacterial, 170: 4165- 4173.

Fatma, M. Darwish; Hammed, A.M. and Hala, S. Ibrahim (2001): pathological studies on pneumonia in camels with special reference to mycotic and bacterial infection. J. Egypt. Vet. Med. Ass., 61( 2): $143-172$.

Finegold, S.M. and Martin, W.T. (1982): Diagnostic Microbiology. $6^{\text {th }}$ ed., the C.V. Mosby Co., U.S.A.

Gardon, A.H. (1980): Electrophoresis of protein in polyacrylamide and starch gels. In laboratory techniques in Biochemistry and Molecular Biology. T. S Work and (Eds) - Elsevier / north Holland Biomedical Press Amsterdam 213 pages.

Hitchcock, P.J. and Brown, T.M. (1983): Microbiological heterogeneity among Salmonella lipopolysaccharide types in silver stained polyacrylamide gels. J. Bacteriol. 184-277.

Jyotsna. Kumari, Unni, B.G.; Ranju.Sarma; WANN S.B.; Utpala.Bora and Kalita, M. (2005): Induction of bactericidal immune protein 
in the haemolymph of muga silkworm, Antheraea assama. Indian. J.of Microbiol., 45(4): 273-276.

Jeenifer M. Bomberger; Daniel P. Macchran and Bruce A. Stanton (2009): Long distance delivery of bacterial virulence factors by Pseudomonas aeruginosa outer membrane vesicles. Plos Pathog. 5 (4).

Khanna, N. D.; Tandon, S.N.; Sahani, M.S.; Allen, W.R.; Kharazmi (1992): Virulence of Pseudomonas aeruginosa. Antibiot. Chemother (Base) 39: 136-148.

King, E.O.; Ward, M.K. and Raney, D.E. (1954): Two simple media for the demonstration of pyocyanin and flurecin. J. Lab. Clin. Med., 44: 301 .

Laemmli, U.K. (1970): Cleavage of structural protein during the assembly of the head of bacteriophage. Nature, 227: 680-685.

Molakala, S. Reddy (1992): Human Tracheobronchial Mucin: Purification and binding to Pseudomonas aeruginosa. Infec. and Immun., 60(4): 1530- 1535.

Oxoid, (1998): The Oxoid Manual 8th Ed. Published by Oxoid Limited wade road, Basing stoke Hampshire RG 248 PW. England.

Pablo, A.; Bejarano; Jan, P.M.; Langeveld; Billy G. Hudson and Milton E. Noelken (1989): Degradation of basement membranes by Pseudomonas aeruginosa Elastase. Infec. and Immun.: 3783- 3787.

Riad, E.M. (1989): Bacteriological observations on the mortality problem in neonatal calves. M.V. Sc. Thesis, Fac. Vet. Med., Cairo University.

Seddak, R.S. (2002): Bacterial causes of lung affections in slaughtered camels in Assiut Governorate. Assiut. Vet. Med. J., 46 (92): 169-177.

Smith, B.J. (1984): SDS polyacrylamide gel electrophoresis of proteins. Meth Mol. Biol. 1:41-56.

Thabet, A.El-R. (1993): Some microbial studies on lung of clinically healthy and respiratory infected camels. Assiut Vet. Med. J., 30 (59): 188-195.

Towbin, H.; Staeceline, T. and Gordan, J. (1979): Electrophoretic transfer of protein from polyacrylamide gel to nitrocellulose sheets. Proc. Nat- Aced- USA. 76: 4350-4354.

Wassenaar, T. and Newell, D.G. (2000): Genotyping of Campylobacter species. Appl. Environm. Microbial. 66: 1-9. 
Assiut Vet. Med. J. Vol. 57 No. 130 July 2011 